\title{
Agriculture faculty students' meanings translation in conditions of the development of communicative competence
}

\author{
Elena Suroedova ${ }^{1, *}$, Yulya Tushnova ${ }^{1}$ and Ekaterina Belousova ${ }^{1}$ \\ ${ }^{1}$ Don State Technical University, 1, Gagarin sq, 344003, Rostov- on-Don, Russia
}

\begin{abstract}
This article discusses psychological characteristics of communicative and speech competence of the agriculture faculty students. The authors pay attention to the study of students communication skills in the process of interaction, their ability to translate meaning, skills of information interpretation and effective meaning transfer. The study involved 120 students aged 17 to 23 years $(M=20.75, S D=2.25$ ( $37 \%$ men). Methods were used: a survey - "Communicative competence" of L. Michelson in the modification of Yu.Z. Gilbukh; testing - subtest No. 6 of the Wechsler test; analytic tasks - a method of supplementing / completing / restoring a speech utterance, a classification method; statistical methods (descriptive statistics, Mann Whitney U test, Kruskal-Wallis test). The study found that first-year students differ from senior students in communicative competence. The speech competence of graduate students in a qualitative aspect is better developed, however, it is distorted by the influence of personal characteristics and the situation. The research prospects are aimed at studying the differences in speech and communicative competence of students who completed training courses on the development of these abilities. It is also promising to study the characteristics of the process of meaning, as variables in the formation of speech and communicative competence.
\end{abstract}

\section{Introduction}

In the process of communication, an exchange of meanings takes place between students: during a speech impact, the communicator broadcasts its own meanings, values, relationships, which are either perceived by the recipient in tune, or are transformed in his mind. The following factors largely determine how communication will develop: how competently and fully the sender of the message is able to convey information; how the recipient will understand the sender, which will show the reaction; the extent to which communication participants are able to correctly identify personal boundaries, show empathy, contact, take initiative in communication, demonstrate general awareness of the subject of conversation. The stated parameters make up the general communicative and speech competence of students.

${ }^{*}$ Corresponding author: suroedova@mail.ru 
Taking into account the modern requirements of employers, one of the tasks of universities is to provide students with the experience of teamwork, promote the development of sociability, the formation of skills in small, project groups. Leontiev D.A. noted, it is impossible to organize long-term productive work of a team without the coordination of group members at the level of meanings, i.e. without the formation and development of communicative and speech competence [1].

In connection with the existence of such a need to improve the communicative and speech competence of students, we conducted a study evaluating the level of development of relevant skills in students.

A theoretical analysis of the problem of speech and communicative competence allowed us to establish that today there are a large number of interpretations of these concepts. In the works of Minaeva S.V. and her colleagues are offered an author's interpretation of the concepts of social and professional communication and social and professional communicative competence. The authors propose to understand by socio-professional communicative competence the totality of knowledge and skills necessary for the exchange of information between people and groups in the field of professional activity [2]. Tsepilova A.V. offers to consider the professional and communicative competence of an engineer as an integrative unity of his professional and communicative skills [3]. In the works of Savvina I.L. and Borisova I.F results of studies that prove, that the communicative competence contributes to successful communication, helps to build effective interpersonal interaction in a variety of situations, contributes to the successful functioning in a professional environment. Communicative competence is associated with communicative skills and is determined by the individual psychological properties of a person [4]. Mustukhanova R.M. highlights the following structural elements of speech competence: the ability to create and understand the various types and genres of stylistically differentiated texts; fluency in oral and written vocabulary and speech in native language; the ability to speak correctly, expressively, fluently both in dialogues and in monologist speech, to be able to understand sounding and written speech; ability to produce speech [5].

The problem of translating meanings in science was dealt with by representatives of psychology, linguistics, pedagogy, and philology. This phenomenon is of an interdisciplinary nature and is of interest in such areas of human life where communication and interaction are necessary, even mediated through signs, symbols, drawings, sounds. The sense transmission or translation of meanings sounds in the context of interpersonal communication, joint activities, pedagogical and advertising influences, cultural artifacts and is understood by different authors as: a way to convey meanings and meanings by verbal-logical or non-verbal-emotional means [6]; focus on the formation of common meanings of objects, that is the formation of a common psychological situation of joint mental activity [7]; as the essence of artistic communication and the purpose of art [1].

Leontyev D.A. identifies three problems in the process of translating meanings for consideration [1]: 1 . How do the concepts of meaning and meaning relate to each other 2 . How are the meanings agreed upon and changed in the process of joint activity. 3. How is the semantic impact on a person or group of people.

In linguistics, the translation of meaning is closely related to the problem of text translation, when meaning always appears in the translation process, and not translation is the product of this process - the process of sense transfer . Andy Bayu Nugroho writes that translating text from source text (ST) should take into account the closest natural equivalent value. This means that the value of the target text should be equivalent to the value of the source text. Value, according to Andy Bayu Nugroho, is divided into two types: referential value and connotative value. The translator should know what meaning the author may have in mind [8]. 
Interesting data presented in papers Yla R. Tausczik1 and James W. Pennebaker. Scientists have identified significant differences in the verbal manifestations of the meaning and translation of the meanings of people of different ages, gender and gender, extra version and introversion and personality traits, a tendency to depression and suicide. The authors conclude that and individual differences, self-focusing, cognitive complexity, social links and emotional tone inherent in the use of language may help identify individual differences, the mental state and the state of human health [9].

In the works of Abakumova I.V., Pronenko E.A., Godunova M.V. the problem is raised with thought strategies as regulators of the personality's modern activity. Researchers have identified two polar strategies for semantic formation: adaptive and developing. The choice of a semantic strategy, according to the authors, is in mutual agreement with personality traits, characteristics of interaction, age and gender, and professional identity. The results indicate the dynamics of the world image of the experiencing subject, which reflects the various effects of strategies for the formation of meanings [10]. Kruteleva L.Ju., Abakumova I.V. in their works present a diagram of the hierarchical semantic sphere of the personality where the life-semantic strategy of a person is defined as an integral psychic formation, an internally shortened program of possible action, determined by the content and motivational-dynamic structural elements of the meaning - value sphere of a person. The authors identified and described the life-semantic strategies of students and their close relationship with various cognitive orientations. They found that students of the same strategy have common stable characteristic-semantic features that affect their educational success [11]. The results of a study by Kozhukhar G., Belousova A. speak about the influence of value orientations on a person's perception of groups and the choice of an interaction strategy in interpersonal communication [12].

Belousova A., Abrosimova L., Bogdanova M. consider speech production as an important factor in the actualization of the personality, which determines the psychological, speech and behavioral and personal activity. To increase the effectiveness of educational activities, it is necessary to introduce the educational process to active methods that allow the formation of knowledge and professional competence, involving students in active cognitive activity. The intensification of the learning process will allow students to go beyond the limits of their individual experience and stimulate the manifestation of willingness to perceive and create new information [13]. Experimentally, the researchers revealed a coefficient of communication intensity and its influence on the effectiveness of group activity and joint mental activity of participants. They believe that the implementation of the proposed methods in teaching contribute to intensification and training, which means, firstly, the creation of the most favorable conditions in the educational process; secondly, the intensification of the educational activities of an individual student; thirdly, the intensification of educational activities in the framework of collective psychological conditions and joint mental activity [13, 14].

In studies Belousova E., Stosic L. was found that in the process of interpreting a visual stimulus (for example, posters) in young people actualization of semantic units, which manifests itself in a trend and evaluate the posters in accordance with the dominant meaning of life. The authors established a connection between the dominant life sense of students and their ratings of advertising posters [15].

The study of the features of speech and communicative competence in the process of translating meanings at different stages of training will reveal the general dynamics of communicative skills in the process of mastering a profession, and see what kind of abilities are formed in this dynamics. 


\section{Materials and Methods}

The empirical base of the study consists of the agriculture faculty students studying at Don State Technical University. A total of 120 people aged 18 to 23 years old took part $(\mathrm{M}=20.75, \mathrm{SD}=2.25$ (37\% men)). Of which, 1st year students were $25 \%(\mathrm{M}=19.1, \mathrm{SD}=1.2$ $(40 \%$ men $)) ; 2^{\text {nd }}$ year students rate $-36.7 \%(\mathrm{M}=20.3, \mathrm{SD}=0.2(40.9 \%$ men $)) ; 3$ year bachelors - 20\% $(\mathrm{M}=20.8, \mathrm{SD}=3.1$ (33.3\% men) $)$; 4nd year students - 18.3\% $(\mathrm{M}=21.8$, $\mathrm{SD}=2.6(27.3 \%$ men $))$.

The purpose of the research work was to study the characteristics of the speech and communication competence of students at different stages of training in the process of translating meanings.

We hypothesized that there may be differences in the communicative and verbal competence in the process of translation of the meanings of bachelor students on different courses of study.

The study was implemented in a number of stages: Stage 1 - the study of the state of the problem and the degree of its relevance, determination of goals, hypotheses and research tasks, selection of methods and techniques of scientific research; Stage 2 - a psycho diagnostic study of the level of communicative competence, the level of vocabulary, speech competence of bachelor students; Stage 3 - processing and analysis of the results.

The study used methods for polling (questionnaire "Communicative competence" L.Mihelson modification Yu.Z. Gilbuha), test (subtest № 6 "Vocabulary" test WAIS (Wechsler Adult Intelligence Scale), analytical tasks (additions technique / completion / restoration of speech utterance, classification method), statistical (descriptive statistics, Mann Whitney U test, Kruskal-Wallis test). Statistical analysis was carried out in the program for processing statistical data PSPP (License: GNU GPL v3). Form of organization of the study - cross- sectional research.

Reliability and accuracy of the research results is provided by the methodological and theoretical validity of the work; using methods adequate to the essence of the phenomena studied, the purpose and objectives of the study; empirical hypothesis testing; quantitative (using mathematical statistics methods) and qualitative analysis of empirical material.

\section{Results}

At the beginning of the study, communication skills were presented to a statistical analysis. Quantitative and qualitative analysis of the results of the study of communicative abilities of the procedure L. Michelson has allowed us to identify that in empirical group on the scale of "The ability to provide and receive tokens" $(\mathrm{M}=1.6, \sigma=0.6)$, "The ability to have compassion, support" $(\mathrm{M}=1.3, \sigma=0.7)$, "The ability to take sympathy, support" $(\mathrm{M}=1.2$, $\sigma=0.7)$, "Responding to his own lack of success and the success of the other" $(M=1$, $\sigma=0.6)$, "Responses to not just criticism" ( $\mathrm{M}=1.3, \sigma=0.7)$, "Response to hurt the provoking issues" $(\mathrm{M}=1.2, \sigma=0.6)$, "The ability to say no to someone else's request" $(\mathrm{M}=1.1, \sigma=0.7)$, "The ability to make contact" $(\mathrm{M}=1.2, \sigma=0.7)$, "Responding to attempt another start contact" $(\mathrm{M}=1.2, \sigma=0.7)$ revealed high levels and mean values. But on the scale of "The ability to refer to a peer with a request" $(\mathrm{M}=0.9, \sigma=0.7)$, "Responding to unfair criticism" $(\mathrm{M}=1, \sigma=0.7)$, "The ability to ask for and accept help" $(\mathrm{M}=0.7, \sigma=0.7)$ there are more low values. To verify the obtained data, we used descriptive statistics, Kruskal-Wallis test, Mann Whitney U test.

We hypothesized that the components of communicative competence may be different among students at different stages of study. This assumption was verified by the Kruskal- 
Wallis test. A pair wise comparison was also made using the Mann Whitney U test, to refine the results.

The results showed the presence of differences in all 4 groups of students in the severity of the following communicative skills: "Ability to turn to a peer with a request", "Ability to provide empathy, support", "Ability to ask and accept help". The result of mathematical statistics is presented in table 1 .

Table 1. Features of the communicative competence of students studying in different courses.

\begin{tabular}{|c|c|c|c|c|}
\hline \multicolumn{2}{|c|}{ Group/Test scale } & $\begin{array}{c}\text { Ability to turn to a } \\
\text { peer with a } \\
\text { request }\end{array}$ & $\begin{array}{c}\text { The ability to provide } \\
\text { empathy, support } \\
\text { yourself }\end{array}$ & $\begin{array}{c}\text { Ability to ask } \\
\text { and accept } \\
\text { help }\end{array}$ \\
\hline $\begin{array}{c}\text { Group 1 }\left(1^{\text {st }} \text { year }\right. \\
\text { students) }\end{array}$ & $\mathrm{n}=30$ & $\mathrm{M}=0.9, \sigma=0.5$ & $\mathrm{M}=1.7, \sigma=0.7$ & $\mathrm{M}=0.9, \sigma=0.6$ \\
\hline $\begin{array}{c}\text { Group 2 }\left(2^{\text {nd }} \text { year }\right. \\
\text { students) }\end{array}$ & $\mathrm{n}=44$ & $\mathrm{M}=1, \sigma=0.6$ & $\mathrm{M}=1.5, \sigma=0.7$ & $\mathrm{M}=0.3, \sigma=0.5$ \\
\hline $\begin{array}{c}\text { Group 3 }\left(3^{\text {rd }} \text { year }\right. \\
\text { students) }\end{array}$ & $\mathrm{n}=24$ & $\mathrm{M}=0.3, \sigma=0.5$ & $\mathrm{M}=1, \sigma=0.6$ & $\mathrm{M}=1.3, \sigma=0.8$ \\
\hline $\begin{array}{c}\text { Group 4 }\left(4^{\mathrm{th}} \text { year }\right. \\
\text { students) }\end{array}$ & $\mathrm{n}=22$ & $\mathrm{M}=1.4, \sigma=0.7$ & $\mathrm{M}=0.9, \sigma=0.7$ & $\mathrm{M}=0.7, \sigma=0.7$ \\
\hline \multicolumn{2}{|c|}{ Kruskal-wallis test } & $01 / 15$ & 9.34 & 14.25 \\
\hline \multicolumn{2}{|c|}{$\mathrm{p}$} & $0.002^{* *}$ & $0.025^{*}$ & $0.003 * *$ \\
\hline
\end{tabular}

Notes: ** - significance level $0.01 ; *$ - significance level 0.05 .

Other communicative skills when comparing 4 groups of students at the same time showed no differences. Therefore, they were analyzed in pairs between groups. Significant differences are presented in table 2.

Table 2. Features of the communicative competence of students studying in different courses (pair comparison).

\begin{tabular}{|c|c|c|c|c|c|c|}
\hline \multirow{3}{*}{$\begin{array}{l}\text { Group/Test } \\
\text { scale }\end{array}$} & \multicolumn{2}{|c|}{$\begin{array}{c}\text { Group } 1\left(1^{\text {st }} \text { year }\right. \\
\text { students }) \text { - Group } 2 \\
\left(2^{\text {nd }} \text { year students }\right) \\
\end{array}$} & \multirow{2}{*}{\multicolumn{2}{|c|}{$\begin{array}{c}\text { Group } 1\left(1^{\text {st }} \text { year }\right. \\
\text { students }) \text { - Group } 3\left(3^{\text {rd }}\right. \\
\text { year students }) \\
n=30 / n=24\end{array}$}} & \multirow{2}{*}{\multicolumn{2}{|c|}{$\begin{array}{c}\text { Group } 1\left(1^{\text {st }} \text { year }\right. \\
\text { students) - Group } 4\left(4^{\text {th }}\right. \\
\text { year students })\end{array}$}} \\
\hline & \multicolumn{2}{|c|}{$n=30 / n=44$} & & & & \\
\hline & $\begin{array}{c}\text { Mann } \\
\text { Whitney U }\end{array}$ & $\mathbf{p}$ & $\begin{array}{c}\text { Mann } \\
\text { Whitney U }\end{array}$ & $\mathbf{p}$ & $\begin{array}{c}\text { Mann } \\
\text { Whitney U }\end{array}$ & p \\
\hline \multirow{2}{*}{$\begin{array}{l}\text { Skills e respond } \\
\text { to } \quad \text { justified } \\
\text { criticism }\end{array}$} & 97.5 & $0.036^{*}$ & & & & \multirow[b]{2}{*}{-} \\
\hline & \multicolumn{2}{|l|}{$\begin{array}{l}M_{1}=1.6, \\
\sigma_{2}=0.8\end{array}$} & & & & \\
\hline \multirow{2}{*}{$\begin{array}{l}\text { Responding to } \\
\text { another attempt } \\
\text { to make contact }\end{array}$} & & & 49.5 & $0.047 *$ & 36.00 & $0.031 *$ \\
\hline & & & \multicolumn{2}{|c|}{$\begin{array}{c}\mathrm{M}_{1}=1.6, \sigma_{1}=0.5 / \mathrm{M}_{3}=1, \\
\sigma_{3}=0.7\end{array}$} & \multicolumn{2}{|c|}{$\begin{aligned} \mathrm{M}_{1}=1.6, \sigma_{1} & =0.5 / \mathrm{M}_{4}=0.9, \\
\sigma_{4} & =0.7\end{aligned}$} \\
\hline
\end{tabular}

Notes: ** - significance level $0.01 ; *$ - significance level 0.05 .

To study speech competence, we used subtest No. 6 "Vocabulary" test WAIS (Wechsler Adult Intelligence Scale). The study found that students in experiential group average low aperture if the meaning of the words of the native language "Money" $(\mathrm{m}=0.4$, $\sigma=0.6)$, "Resisting" $(\mathrm{m}=0.4, \sigma=0.6)$, "Calm" $(\mathrm{m}=0.6, \sigma=0.7)$, "Building" $(\mathrm{m}=0.5, \sigma=0.7)$, "Bold" ( $\mathrm{m}=0.6, \sigma=0.6)$, "Clutter" ( $\mathrm{m}=0.6, \sigma=0.8)$, "Pierce" ( $\mathrm{m}=0.6, \sigma=0.81)$, "Parody" $(\mathrm{m}=0.4, \sigma=0.6)$, "Plagiarism" ( $\mathrm{m}=0.5, \sigma=0.8)$, "Sinister" ( $\mathrm{m}=0.6, \sigma=0.7)$, "Pity" ( $\mathrm{m}=0.6$, $\sigma=0.8)$, "The Temple" ( $\mathrm{m}=0.6, \sigma=0.8)$, "Incomparable" $(\mathrm{m}=0.6, \sigma=0.7)$. These data allow us to say that students lack the accuracy of the interpretation of the meaning of words, the skills of effective translation of meaning. The meaning of the word "Cave" $(\mathrm{m}=1.3, \sigma=0.8)$ most accurately revealed the majority of students. The data obtained allow us to talk about 
the low level of speech competence of students and the ability to translate meanings by verbal means. Comparative analysis of (Kruskal-Wallis test) speech competence (KruskalWallis test) in students at different rates, showed differences $(\alpha=0.05)$ in the efficacy of interpretation of the word "Plagiarism" $(\mathrm{H}=8.18, \mathrm{p}=0.042)$. The highest average interpretation score for this word is presented in 1st year students $(\mathrm{m}=0.9, \sigma=0.9)$ and 4 courses $(m=0.6, \sigma=0.97)$. It should be noted that these values are less than unity, subject to a maximum score of 2 points. Students of 2 courses $(m=0.3, \sigma=0.7)$ and 3 courses $(m=0.3$, $\sigma=0.8$ ) have the same average grade.

To clarify the results, a pair wise comparison (Mann Whitney U test ) between the groups of the presented array of words was carried out. Differences in the interpretation of words, their meaning are presented in table 3 .

Table 3. Features of the speech competence of students studying in different courses (pair comparison).

\begin{tabular}{|c|c|c|c|c|c|c|}
\hline \multirow{3}{*}{$\begin{array}{l}\text { Group/Test } \\
\text { scale }\end{array}$} & \multirow{2}{*}{\multicolumn{2}{|c|}{$\begin{array}{c}\text { Group } 1\left(1^{\text {st }} \text { year }\right. \\
\text { students) - Group } 2\left(2^{\text {nd }}\right. \\
\text { year students }) \\
\end{array}$}} & \multirow{2}{*}{\multicolumn{2}{|c|}{$\begin{array}{c}\text { Group } 1\left(1^{\text {st }} \text { year }\right. \\
\text { students) - Group } 4\left(4^{\text {th }}\right. \\
\text { year students }) \\
n=30 / n=22\end{array}$}} & \multirow{2}{*}{\multicolumn{2}{|c|}{$\begin{array}{c}\text { Group } 3\left(3^{\text {rd }} \text { year }\right. \\
\text { students) - Group } 4\left(4^{\text {th }}\right. \\
\text { year students }) \\
n=24 / n=22\end{array}$}} \\
\hline & & & & & & \\
\hline & $\begin{array}{c}\text { Mann } \\
\text { Whitney U }\end{array}$ & $\mathbf{p}$ & $\begin{array}{c}\text { Mann } \\
\text { Whitney U }\end{array}$ & $\mathbf{p}$ & $\begin{array}{c}\text { Mann } \\
\text { Whitney U }\end{array}$ & $\mathbf{p}$ \\
\hline \multirow[b]{2}{*}{ Hide } & 101.5 & $0.045^{*}$ & \multirow{2}{*}{ 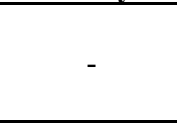 } & \multirow[b]{2}{*}{-} & \multirow[b]{2}{*}{-} & \multirow[b]{2}{*}{-} \\
\hline & \multicolumn{2}{|c|}{$\begin{array}{l}\mathrm{M}_{1}=0.7, \sigma_{1}=0.7 / \\
\mathrm{M}_{2}=1.2, \sigma_{2}=0.7\end{array}$} & & & & \\
\hline \multirow[b]{2}{*}{ Disaster } & 97,0 & $0.036^{*}$ & \multirow[b]{2}{*}{-} & \multirow[b]{2}{*}{-} & \multirow[b]{2}{*}{-} & \multirow[b]{2}{*}{-} \\
\hline & \multicolumn{2}{|c|}{$\begin{array}{l}\mathrm{M}_{1}=0.7, \sigma_{1}=0.6 / \\
\mathrm{M}_{2}=1.3, \sigma_{2}=0.7\end{array}$} & & & & \\
\hline \multirow[b]{2}{*}{ Huge } & \multirow[b]{2}{*}{-} & \multirow[b]{2}{*}{ - } & 40.00 & $0.050 *$ & & \\
\hline & & & \multicolumn{2}{|c|}{$\begin{aligned} \mathrm{M}_{1}=0.8, \sigma_{1} & =0.8 / \mathrm{M}_{4}=1.4, \\
\sigma_{4} & =0.8\end{aligned}$} & & \\
\hline \multirow[b]{2}{*}{ Incomparable } & \multirow[b]{2}{*}{-} & \multirow[b]{2}{*}{-} & \multirow[b]{2}{*}{-} & \multirow[b]{2}{*}{-} & 26.00 & $0.025^{*}$ \\
\hline & & & & & \multicolumn{2}{|c|}{$\begin{array}{c}\mathrm{M}_{3}=0.3, \sigma_{3}=0.5 / \mathrm{M}_{4}=1, \\
\sigma_{4}=0.8\end{array}$} \\
\hline
\end{tabular}

Notes: ** - significance level $0.01 ; *$ - significance level 0.05 .

Using the methodology, analytical tasks (the method of supplementing / completing / restoring a speech utterance, the classification method) we were also able to identify some features of the speech competence of students studying in different courses (KruskalWallis test). During the assignment, students were asked to fill in the missing words in the text. At the end of the assignment, the text should be characterized by such qualities as understandability, accuracy, consistency and coherence, culture, since it is these indicators that reflect the ability to most accurately convey meaning. The results of a comparative analysis of the quality of the assignment are presented in table 4.

Table 4. On the characteristics and verbal competence of students received by the method of analytical tasks.

\begin{tabular}{|c|c|c|c|}
\hline \multicolumn{2}{|c|}{ Group/Test scale } & Missing words & $\begin{array}{c}\text { Correctly chosen words that are } \\
\text { appropriate in meaning and accurately } \\
\text { reflect the essence of the text }\end{array}$ \\
\hline $\begin{array}{c}\text { Group 1 }\left(1^{\text {st }}\right. \\
\text { year students) }\end{array}$ & $\begin{array}{c}\mathrm{n}= \\
30\end{array}$ & $\mathrm{M}=7.7, \sigma=7.4$ & $\mathrm{M}=8.7, \sigma=4.6$ \\
\hline $\begin{array}{c}\text { Group 2 }\left(2^{\text {nd }}\right. \\
\text { year students) }\end{array}$ & $\begin{array}{c}\mathrm{n}= \\
44\end{array}$ & $\mathrm{M}=2.4, \sigma=4.3$ & $\mathrm{M}=11.5, \sigma=4.5$ \\
\hline Group 3 $\left(3^{\text {rd }}\right.$ & $\mathrm{n}=$ & $\mathrm{M}=7.8, \sigma=3.7$ & $\mathrm{M}=10.6, \sigma=5$ \\
\hline
\end{tabular}




\begin{tabular}{|c|c|c|c|}
\hline year students) & 24 & & \\
\hline $\begin{array}{c}\text { Group 4 }\left(4^{\text {th }}\right. \\
\text { year students })\end{array}$ & $\begin{array}{c}\mathrm{n}= \\
22\end{array}$ & $\mathrm{M}=9.6, \sigma=5.9$ & $\mathrm{M}=7.4, \sigma=4.5$ \\
\hline Kruskal-wallis test & 19.5 & 8.55 \\
\hline $\mathrm{p}$ & $0.000^{* *}$ & $0.036^{*}$ \\
\hline
\end{tabular}

Notes: ** - significance level 0.01; * - significance level 0.05 .

\section{Discussion}

The results of the study of the features of communicative competence by the method of L. Michelson allowed us to identify differences in the level of development of some communicative skills. It was found that scores on "Responding to fair criticism" and "Ability to ask for and accept help" more pronounced among students of 1 course. In the group of $2^{\text {nd }}$ year students, high indicators of communicative skills were not revealed, but low values were found for the skills "Responding to fair criticism" and "Responding to unfair criticism". Higher rates among 3rd ear students, unlike other students, were identified on the scales of "Responding to unfair criticism", "Ability to ask and accept help" and "Responding to touching, provocative questions". However, scales with lower indicators than students of other courses were identified: "Ability to turn to a peer with a request", "Ability to render empathy and support on one's own". Indicators on the scales of the methodology "Ability to give and receive signs of attention", "Ability to turn to a peer with a request", "Ability to refuse a request from someone else", "Ability to render sympathy, support", "Ability to accept sympathy, support" are more expressed in 4 year students. On the scales "Ability to make contact" and "Responding to an attempt by another to make contact", 4-year students have lower average values than groups of junior students. The results of the comparative analysis revealed some features in the level of development of communication skills in students of different courses.

It was shown that there are differences in the severity of the communicative skills "Ability to turn to a peer with a request", "Ability to render sympathy, support for oneself", "Ability to ask and accept help". In this case, the ability to turn to a peer for help is more pronounced among 4-year students. The general ability to ask and accept help, outside the context of a peer, is expressed in students of 1 and 3 courses. And the ability to provide support and sympathy for students of 1 and 2 courses. That is, considering the development of communicative competence, we can conclude that by the $4^{\text {th }}$ year the ability to turn for help is limited to a circle of peers. This may be due to an increase in the overall competence of peers, a positive assessment of their personal and professional resources. At the same time, the ability to provide support is more typical for junior students.

Pairwise comparisons made it possible to detail the results of a study of communicative competence. Significant differences were shown between the groups of students 1 and 2 courses of study in at ability and respond to the justified criticism. These data indicate that 1 st year students are more susceptible to constructive criticism, can defend their interests and needs, seek clarification of the situation, the meaning of the tasks and assignments.

Significant differences in the ability to respond to the attempt of another to make contact between groups of students of 1 and 3 courses of study, as well as 1 and 4 courses are also revealed. The data obtained suggest that the students of 1 course easier to come into contact, have the skills to establish contacts, discover, share their knowledge and experience, trying to explain the motives of their actions and activities. The results of pairwise comparisons clarify the general conclusion that 1 st year students have more developed communicative skills. These findings are somewhat contrary to the general concept of learning. 
The features of speech competence of students of different courses of study are observed. We have identified differences between groups of students in understanding and accuracy of interpretation of the meaning and meaning of stimulus words: $2^{\text {nd }}$ year students interpret the words "hide" and "distress" much better than $1^{\text {st }}$ year students; the meaning of the word "huge" is better interpreted and understood by 4-year students than 1-year students; 4th year students interpret the word "incomparable" much better and more accurately than 3rd year students; the word "plagiarism" is more fully interpreted by students of 1 and 4 courses of study than 2 and 3 courses.

In general, the results of the study of speech competence indicate that students lack the accuracy of the interpretation of the meaning of words, the skills of effective translation of meaning. A study of the ability of students to operate with the words of their native language showed that $4^{\text {th }}$ year students are somewhat better at interpreting and translating the meanings and meanings of words. In addition, the results obtained by the method of subtest No. 6 "Vocabulary" test WAIS (Wechsler Adult Intelligence Scale) allow us to assert that 4th year students have a higher level of thinking culture and a large vocabulary, a good sense of proportion and adequacy in determining the meaning words-stimulus and translation of the meaning of the word, higher efficiency of meaning.

Analysis of the results obtained using the methodology of analytical tasks in four groups showed that the greatest number of omissions in the tasks was noted among students of 4 courses and 1 course of study. While in the group of $2^{\text {nd }}$ year students the smallest number of omissions in the text was established. It was also revealed that the largest number of selected synonyms and words that are close in meaning to the place of the missing stimulus words in the task was established in the group of students of the 1st year of study. Student's 2 courses, in contrast to the 1st year students learning excelled more precise choice of words. In their studies revealed using less number of synonyms, than in the other groups.

It was found that in the works of students of the 1st year of study, most often during the assignment words were selected that were not suitable for the meaning of the text, they violated its logic, coherence and accuracy of sensory transmission. In the works of students of the $4^{\text {th }}$ year of study, the smallest number of words that were incorrectly selected in terms of meaning was revealed, but at the same time it is necessary to recall that in this group there are more gaps in comparison with other groups. This suggests that when faced with the complexity of the choice of words that most accurately reflects the essence and meaning, without violating the logic of the text and its $4^{\text {th }}$ year students connectivity refused the assignment. Thus, the strategy for solving the task of 1 st year students - to pick up any word that even violates the logic of the text, and 4 courses - not to choose words, negatively affect the translation of the meaning and effectiveness of meaning;

From among four groups of students, when solving the task of choosing substitute words, the greatest number of exact answers, that is, selected words that are suitable in meaning and do not violate the integrity and consistency of the text, was noted in 3 year students. Students of the 1 st and 2 nd year of study showed low results when completing the task of selecting words that reflect the meaning of the text, its accuracy, clarity and logic. These data allow us to say that $1^{\text {st }}$ and $2^{\text {nd }}$ year students have slightly less developed skills for translating meanings and effective meaning, speech competence is less developed than $3^{\text {rd }}$ and $4^{\text {th }}$ year students.

The results of mathematical statistics made it possible to establish that there are significant differences in terms of speech competence: the presence of missing words and correctly selected criteria, words that are suitable in meaning and accurately reflect the essence of the text.

From the first-year students, they differ from the second-year students by the criterion "the number of missing words in the text". When completing the assignment, $1^{\text {st }}$ year students are much more likely to miss words, which indicates a low ability of the subjects 
to accurately select words reflecting the meaning, a small vocabulary, and a low level of development of the ability to transmit meaning.

From the second-year students, they differ from the third-year students in their greater ability to select words in the text, they performed the task more efficiently and omissions were rarely observed in their texts.

The differences between the groups of 2 nd and 4 th year students in the parameters "the number of missing words in the text" and "the number of precisely selected words" were revealed. The data obtained allowed us to establish that $2^{\text {nd }}$ year students tried to better complete the task, picking up more missing words in the text. However, $4^{\text {th }}$ year students differ from $2^{\text {nd }}$ year students in the accuracy of the words chosen in the text, that is, they more accurately and correctly select the words according to the meaning, which makes the text acquire qualities and meaningfulness and logic. The data obtained are inconsistent. More accurate for the transfer of meaning are distinguished by senior students. They try to understand the meaning of the text and choose words that are more appropriate in the context. But in case of frustration and not being able to solve the problem correctly, they refuse further work. 2nd year students choose a strategy to complete the task in any case, even if it is not solved correctly.

Thus, the study revealed differences in the manifestations of communicative and speech competence among the agriculture faculty students. However, the data obtained are contradictory and do not give us the opportunity to argue that the educational environment intensifies the process of formation of communicative-speech competence. We can agree with the researchers Minaeva S.V., Nikolaeva V.V., Puzyreva E.Yu., Ryabinina M.V., Yakovleva T.I., Rubaeva V.P., Delieva L.M., Tedtov I.E., Covellina T.A., Ovsyannikova E.K., Maruhno V.M., Mutuskhanova R.M., Malyuga, E.N, Ponomarenko E.V. is that there is a need to introduce in the educational process courses on communicative and speech competence, which is formed in the process of direct interaction of participants in the educational process, in the course of broadcasting the meanings of subjects of education $[2$, $5,16,17,18]$.

\section{Conclusions}

The results of a study aimed at communicative and speech competence among the agriculture faculty students while they are transferring meanings allowed us to draw the following conclusions.

First-year students are more likely to come into contact with unfamiliar people, they have developed the ability to respond to fair criticism. $4^{\text {th }}$ year students, unlike junior students, demonstrate better ability to turn to peers for help.

Results of the study of speech competence allowed us to establish that the students $f$ average rates show higher verbal abilities and skills. $4^{\text {th }}$ year students are more accurate in transmitting the meanings and meanings of words, interpret words better.

The research prospects are aimed at studying the differences in speech and communicative competence of students who completed training courses on the development of these abilities. It is also promising to study the characteristics of the process of meaning, as variables in the formation of speech and communicative competence.

\section{References}

1. D. Leontiev, Journal of positive psychology 8(6), 457-458 (2013)

2. S. Minaeva, V. Nikolaeva, E. Puzyreva, M. Ryabinina, T. Yakovleva, Social relations 2(25), 31-43 (2018) 
3. A. Tsepilova, Tomsk State Pedagogical University Bulletin 1(178), 87-92 (2017)

4. I. Savvina, I. Borisova, The world of science, culture and education 6(73), 101-102 (2018)

5. R. Mutushanova, Reflection 4, 41-45 (2016)

6. E. Suroedova, Book of abstracts: XVI European congress of psychology (ECP 2019) (Lomonosov Moscow State University, Moscow, 2019)

7. A. Belousova, G. Kozhukhar, L. Ryumshina, Proceedings $8^{\text {th }}$ International Conference of Education, Research and Innovation (Seville, Spain, 2015)

8. A. Bayu Nugroho, UII Journal of English and Education 1(2), 66-74 (2007)

9. Y. Tausczik, J. Pennebaker, Journal of Language and Social Psychology 29(1), 24 -54 (2010) DOI:10.1177/0261927X09351676

10. I. Abakumova, E. Pronenko, M. Godunov, SHS Web Conf. 70, 01001 (2019) DOI: https://doi.org/10.1051/shsconf/20197001001

11. L. Kruteleva, I. Abakumova, Procedia - Social and Behavioral Sciences 86, 35 - 41 (2013)

12. G. Kozhukhar, A. Belousova, Proceedings of EDULEARN17 Conference (Barcelona, Spain, 2017) doi: doi.org/10.21125/edulearn.2017

13. A. Belousova, L. Abrosimova, M. Bogdanova, INTED2017 Proceedings. 11th International Technology, Education and Development Conference (Valencia, Spain, 2017) doi: 10.21125/inted.2017.0577

14. A. Belousova, L. Abrosimova, M. Bogdanova, INTED2017 Proceedings. 11th International Technology, Education and Development Conference (Valencia, Spain, 2017) doi: 10.21125/inted.2017.0576

15. E. Belousova, L. Stosic, SHS Web Conf. 70, 08007 (2019) DOI: https://doi.org/10.1051/shsconf/20197008007

16. V. Rubaeva, L. Delieva, I.Tedtov, Sciences of Europe 28-4(28), 50-52 (2018)

17. T. Kovelina, E. Ovsyannikova, V. Marukhno, International journal of applied and fundamental research 4-1, 175-177 (2016)

18. E. Malyuga, E. Ponomarenko, Proceedings of EDULEARN15 Conference (Barcelona, Spain, 2017) 